\title{
Product/Service-Systems for a Circular Economy: The Route to Decoupling Economic Growth from Resource Consumption?
}

Kjær, Louise Laumann; Pigosso, Daniela C. A.; Niero, Monia; Bech, Nynne Marie; McAloone, Tim C.

Published in:

Journal of Industrial Ecology

Link to article, DOI:

10.1111/jiec.12747

Publication date:

2019

Document Version

Peer reviewed version

Link back to DTU Orbit

Citation (APA):

Kjær, L. L., Pigosso, D. C. A., Niero, M., Bech, N. M., \& McAloone, T. C. (2019). Product/Service-Systems for a Circular Economy: The Route to Decoupling Economic Growth from Resource Consumption? Journal of Industrial Ecology, 23(1), 22-35. https://doi.org/10.1111/jiec.12747

\section{General rights}

Copyright and moral rights for the publications made accessible in the public portal are retained by the authors and/or other copyright owners and it is a condition of accessing publications that users recognise and abide by the legal requirements associated with these rights.

- Users may download and print one copy of any publication from the public portal for the purpose of private study or research.

- You may not further distribute the material or use it for any profit-making activity or commercial gain

- You may freely distribute the URL identifying the publication in the public portal 
Forum paper for Journal of Industrial Ecology

(initially submitted for special issue on: "Exploring the Circular Economy”)

\title{
Product/Service-Systems for a Circular Economy: the route to decoupling economic growth from resource consumption?
}

\author{
Louise Laumann Kjaer*, Daniela C. A. Pigosso, Monia Niero, \\ Nynne Marie Bech, Tim C. McAloone
}

\begin{abstract}
*Corresponding author
Address correspondence to:

Louise Laumann Kjaer

Produktionstorvet building 426

llkj@mek.dtu.dk
\end{abstract}

\section{Summary}

Product/Service-Systems that focus on selling service and performance instead of products are often mentioned as means to realize a Circular Economy, in which economic growth is decoupled from resource consumption. However, a Product/Service-System is no implicit guarantee for a Circular Economy, and Circular Economy strategies do not necessarily lead to decoupling economic growth from resource consumption in absolute terms. Absolute resource decoupling only occurs when the resource use declines, irrespectively of the growth rate of the economic driver. In this forum paper, we propose a two-step framework that aims at supporting analyses of Product/Service-Systems and their potential to lead to absolute resource decoupling. In the first step, we present four Product/Service-System enablers of relative resource reduction that qualify as Circular Economy strategies. In the second step, three subsequent requirements need to be met, in order to successfully achieve absolute resource decoupling. Conditions and limitations for this accomplishment are discussed. Danish textile cases are used to exemplify the framework elements and its application. We expect that the framework will challenge the debate on the necessary conditions for Circular Economy strategies to ensure absolute resource decoupling. 
Kjær, L. L., Pigosso, D. C. A., Niero, M., Bech, N. M., \& McAloone, T. C. (2018). Product/Service-Systems for a Circular Economy: The Route to Decoupling Economic Growth from Resource Consumption? Journal of Industrial Ecology. DOI : $10.1111 /$ jiec. 12747

\section{$<$ heading level 1> Introduction}

The Ellen MacArthur Foundation has stated that "The circular economy provides multiple value creation mechanisms that are decoupled from the consumption of finite resources." (Ellen MacArthur Foundation 2015a, p. 22). Circular Economy (CE) is increasingly seen as a solution to tackle the current resource scarcity issue while ensuring economic growth and job creation (EC (European Commission) 2015).

CE is often linked to the performance economy, where goods are sold as services through business models based on renting, leasing and sharing, while the manufacturer retains ownership of the product (Stahel 2010). The idea of using "a mix of tangible products and intangible services designed and combined so that they are jointly capable of fulfilling final customer needs" (Tukker and Tischner 2006a, p. 1552) is at the core of the Product/Service-System (PSS) concept.

In the editorial of Journal of Industrial Ecology's special issue on CE, PSS were highlighted as means to facilitate CE through e.g. product life extension and product sharing (Bocken et al. 2017). Given the fact that PSS are often mentioned as means to realize CE, there is a risk that all PSS could be perceived to have this potential. However, PSS do not automatically lead to a reduction in resource use, as previously highlighted by several authors (e.g. Tukker 2004; Pigosso et al. 2010; Kjaer et al. 2016; Tukker and Tischner 2006b). In addition, strategies aiming at resource reduction do not automatically lead to an enhanced sustainability performance (Bilitewski 2012; Andersen 2007). In the above-mentioned special issue on CE, an important question (among others) was raised: “when do CE practices lead to net environmental benefits?” (Bocken et al. 2017, p. 1). This was on the agenda in Zink and Geyer (2017)'s paper on CE rebounds, explicitly challenging the ability of CE to live up to the concept's intuitive promise of reducing environmental impacts through less production and consumption. While their argumentation adds valuable inputs to the discussion we aim to raise with this forum paper, there is still a need to explicitly address and clarify the resource decoupling potential of CE strategies in the context of PSS. Resource decoupling represents the aim of decoupling economic growth from resource consumption. Resource decoupling seeks to reduce the rate of resource depletion and costs by raising resource productivity, which is expected to simultaneously reduce environmental impacts (UNEP 2011). Resource decoupling can be relative or absolute. While relative resource decoupling focuses on obtaining less environmental damage per growth rate, absolute resource decoupling occurs when the resource use declines, irrespective of the growth rate of the economic driver (UNEP 2011). In a growing population with an increasing average income, absolute decoupling will occur when the rate of relative decoupling is greater than the rates of increase in population and income combined 
Kjær, L. L., Pigosso, D. C. A., Niero, M., Bech, N. M., \& McAloone, T. C. (2018). Product/Service-Systems for a Circular Economy: The Route to Decoupling Economic Growth from Resource Consumption? Journal of Industrial Ecology. DOI : $10.1111 /$ jiec. 12747

(Jackson 2009). Since relative decoupling is not enough to ensure an overall decline in resource consumption, this paper focuses on absolute resource decoupling.

The questions we aim to answer with this forum paper are: "When does PSS enable a CE strategy? And when does a CE strategy lead to absolute resource decoupling?”

With this paper, we wish to inspire a more critical view when proposing PSS as means to enable CE. Such proposals should be supplemented with arguments on how the PSS enables a relative resource reduction and ultimately how absolute resource decoupling can be ensured. Therefore, we provide an initial attempt to show the complex route from PSS to absolute resource decoupling with the purpose to initiate a discussion on how to guide future research that can help increase the probability of CE strategies actually fulfilling the ultimate sustainability-related goal of absolute resource decoupling.

\section{$<$ heading level 2> Aims and limitations of CIRCULAR ECONOMY (CE)}

While the concept of CE and its practice have been mostly developed and led by practitioners, i.e. consultants, business foundations and policy-makers, the scientific research content is still young (Korhonen et al. 2018). CE traces back to different schools of thought (Ghisellini et al. 2016), ranging from Environmental Economics to General Systems Theory, from Industrial Ecology to more recent theories about the Performance Economy (Stahel 2010), Cradle-to-Cradle, (McDonough and Braungart 2002), Biomimicry (Benyus 2002) and Blue Economy (Pauli 2010).

Blomsma and Brennan (2017) found that CE offers a new framing around the multitude of waste and resource strategies and provides a discursive space for debate on how they relate to each other in terms of trade-offs and synergies.

Geissdoerfer et al. (2017) combined different contributions in the field and defined CE as " $a$ regenerative system in which resource input and waste, emission, and energy leakage are minimized by slowing, closing, and narrowing material and energy loops. This can be achieved through long-lasting design, maintenance, repair, reuse, remanufacturing, refurbishing, and recycling” (p. 759). As such, CE incorporates several actions for waste minimization and reduction of virgin resource consumption, all of which are linked to the three main "actions” within the 3R's principles: Reduce, Reuse and Recycle (Ghisellini et al. 2016). A comprehensive review of CE definitions by Kirchherr et al. (2017) showed that the 3R framework was the most commonly employed conceptualization of the 'how-to' of CE. The 3R's are embedded in the well-known CE illustration, depicting the so-called technical and biological metabolisms (Ellen MacArthur Foundation 2013). The technical metabolism illustrates how the value of technical materials should be kept through continuous loops based on strategies such as maintain (i.e. inner loop based on 
Kjær, L. L., Pigosso, D. C. A., Niero, M., Bech, N. M., \& McAloone, T. C. (2018). Product/Service-Systems for a Circular Economy: The Route to Decoupling Economic Growth from Resource Consumption? Journal of Industrial Ecology. DOI : $10.1111 /$ jiec. 12747

reduce), reuse/redistribute and refurbish/remanufacture (i.e. middle loops based on reuse), and recycle (i.e. outer loop).

Some authors challenge the focus of CE on waste minimization and resource reduction. They emphasize the beneficial design and innovation opportunities of the CE (e.g. De Pauw et al. 2014; Braungart et al. 2007; McDonough and Braungart 2013) and argue for the importance of supporting “eco-efficiency" with "eco-effectiveness”, where products maintain their value over time to positively recouple the relationship between economy and ecology (Ellen MacArthur Foundation 2013).

In this paper we take the position that the ultimate aim of CE is to keep the value of products, materials and resources in the economy for as long as possible, and to minimize waste generation, i.e. ultimately reducing resource consumption. Furthermore, CE as a concept also focuses on economic value creation (Lieder and Rashid 2015). Thus, we believe that the CE concept should aim at combining an overall reduction in resource consumption with business opportunities, i.e. to ensure absolute resource decoupling. Making absolute resource decoupling operational in a business context is however not straightforward and some challenges have to be overcome.

While CE strategies may incorporate all of the 3R's, CE practitioners often emphasise circular strategies aiming at “closing loops”, i.e. reuse and recycle (Kirchherr et al. 2017). A challenge here, however, is that initiatives aimed at reusing and recycling resources will only reduce primary production when secondary products/materials actually displace the primary production (Zink and Geyer 2017). In a reality of growing demands, secondary (reused/remanufactured/recycled) products are often sold in addition to primary (new) products, resulting in environmental impacts of both the primary and secondary production (Zink and Geyer 2017). Thus, in order to ensure a net resource reduction, CE strategies based on reuse and recycle should confirm that actual “displacement” takes place. Furthermore, Geissdoerfer et al. (2017) found that “...it seems clear to most authors that the Circular Economy is aiming at a closed loop, eliminating all resource inputs and waste and emission leakages of the system..." (p. 8). If this is truly the goal of CE and the perception within the $\mathrm{CE}$ community, this would ignore that also circular systems consume resources and create waste and emissions. There are technical limitations to materials recycling (Grosso et al. 2017) as well as dissipative losses in any loops, thus the vision of $100 \%$ material recycling may still be regarded as only theoretically possible in a distant future (Korhonen et al. 2018), and the feasibility of a closed loop economy is still unknown (Haupt and Zschokke 2017).

Another issue in assessing the effectiveness of CE strategies is to avoid to optimize one stage of the life cycle (e.g. end-of-life) at the expense of other stages (e.g. production) (Niero and Hauschild 2017). A systemic life cycle perspective is therefore needed to avoid such burden shifting between 
Kjær, L. L., Pigosso, D. C. A., Niero, M., Bech, N. M., \& McAloone, T. C. (2018). Product/Service-Systems for a Circular Economy: The Route to Decoupling Economic Growth from Resource Consumption? Journal of Industrial Ecology. DOI : $10.1111 /$ jiec. 12747

life cycle stages. Lastly, when discussing the transition from a relative to absolute resource reduction, evidence is emerging in the literature, detailing the challenge of overcoming the effect by which improvements in efficiency lead to increases in the quantity of goods and services that are provided and consumed, namely “rebound effects” (Dahmus and Gutowski 2011). Speculations or reports about rebound effects are also evident in connection with CE (Haupt and Zschokke 2017; Bocken et al. 2014; Dahmus and Gutowski 2011; Korhonen et al. 2018).

\section{$<$ heading level 2> Aims and limitations of PRODUCT/SERVICE-SYSTEMS (PSS)}

Even though PSS originates from a strong sustainability perspective, a shift in focus from environmental benefits to economic benefits has occurred during the last decade (Haase et al. 2017). PSS are increasingly seen as business strategies created by companies that intend to strengthen their market position and create a competitive advantage by other than traditional transactional product sales.

The most dominant way of describing PSS in the literature (Tukker 2015) distinguishes three types of PSS, as follows:

- Product-oriented PSS: Products are sold to the user, but additional services are added, such as maintenance or product-related consultancy.

- Use-oriented PSS: The business model is geared towards selling the product function, i.e. through leasing or renting and the product remains the ownership of the PSS provider.

- Result-oriented PSS: The business model is geared towards selling a result and is as such closest to offering a pure service, where no predetermined product is involved.

PSS is often recognized as a promising approach to enhance the sustainability performance of traditional product systems, due to its potential to improve resource efficiency by extending the product lifetime and decoupling value from the delivery of physical products. However, PSS are no guarantee for resource reduction, let alone absolute resource decoupling. For example, product leasing is not automatically "greener" (Agrawal et al. 2012), but might in contrast inspire more frequent replacements of products. Also, in the case of sharing systems such as car-sharing, these systems often lead to more people gaining easier access to products (Madsen 2015), which will ultimately increase consumption rather than avoiding it. Take-back services may entail product redistribution and remanufacturing. However, as also discussed in relation to CE, second-hand products do not always replace new products (Thomas 2003), and when sold at lower prices the result is often an overall increase in consumption. From a business perspective, this is positive, as it avoids the cannibalization of the current market for new products, but it does not lead to overall resource reduction. 
Kjær, L. L., Pigosso, D. C. A., Niero, M., Bech, N. M., \& McAloone, T. C. (2018). Product/Service-Systems for a Circular Economy: The Route to Decoupling Economic Growth from Resource Consumption? Journal of Industrial Ecology. DOI : $10.1111 /$ jiec. 12747

Rebound effects in relation to PSS are also a commonly known issue (Kjaer et al. 2016), because a PSS often causes changes in user behavior, which counteracts the resource reduction potential (Mylan 2015; Goedkoop et al. 1999).

<heading level 2> From PSS to absolute resource decoupling - A proposed two-step framework So, how to increase the likelihood of PSS to lead to absolute resource decoupling through CE? We suggest a two-step framework, where firstly, (i) the PSS should enable a relative resource reduction to qualify as a CE strategy (PSS $\rightarrow$ CE strategy) and secondly (ii), the CE strategy must ultimately lead to absolute resource decoupling (CE strategy $\rightarrow$ absolute resource decoupling).

The framework was developed through a review of literature on PSS strategies and their potential to enable absolute resource decoupling. The scientific databases Scopus and Web of Science were searched for journal articles from year 2000 to August 2017, where the resource and/or environmental impact reduction potential of PSS where either assessed (qualitatively or quantitatively) or discussed. Keywords included: "product service system” and related synonyms (e.g. integrated solution, functional offering) and "sustainability evaluation” and related synonyms (e.g. life cycle assessment, eco-efficiency). Through citation analysis, the collection was enhanced with relevant conference papers and grey literature (reports). Based on screenings of titles and abstracts, a total of 106 publications were collected, composing 15 review articles, 65 conceptual publications (primary focus to discuss PSS or propose assessment methods) and 26 case studies (primary focus to assess specific PSS cases). Based on the review, five distinct PSS strategies were identified and on the basis of how the literature discusses their resource reduction potentials, four PSS enablers of resource reduction were derived. These are presented in the subsequent section, presenting step one of the framework. The second step of the framework was developed on basis of the same review, now with the aim of identifying challenges and limitations for PSS to result in absolute resource decoupling. Through the lenses of life cycle assessment (LCA) methodology, which is recognized as an important decision support tool in the CE context (Strothman and Sonnemann (2017); Haupt and Zschokke (2017)), a supplementary review of literature discussing limitations of CE and resource efficiency was conducted as presented in the introduction section of this paper. The challenges and limitations for PSS and CE to lead to absolute resource decoupling were consolidated into three subsequent requirements, composing step two of the framework.

\section{$<$ heading level 1> Framework step one: PSS enablers of resource reduction}


Kjær, L. L., Pigosso, D. C. A., Niero, M., Bech, N. M., \& McAloone, T. C. (2018). Product/Service-Systems for a Circular Economy: The Route to Decoupling Economic Growth from Resource Consumption? Journal of Industrial Ecology. DOI : $10.1111 /$ jiec. 12747

Figure 1 shows the overall framework, comprising the two steps. This section discusses step one, where the PSS enablers of resource reduction are linking PSS to CE strategies through two intermediaries: the PSS strategies (the business actions) and the resource reduction aims.

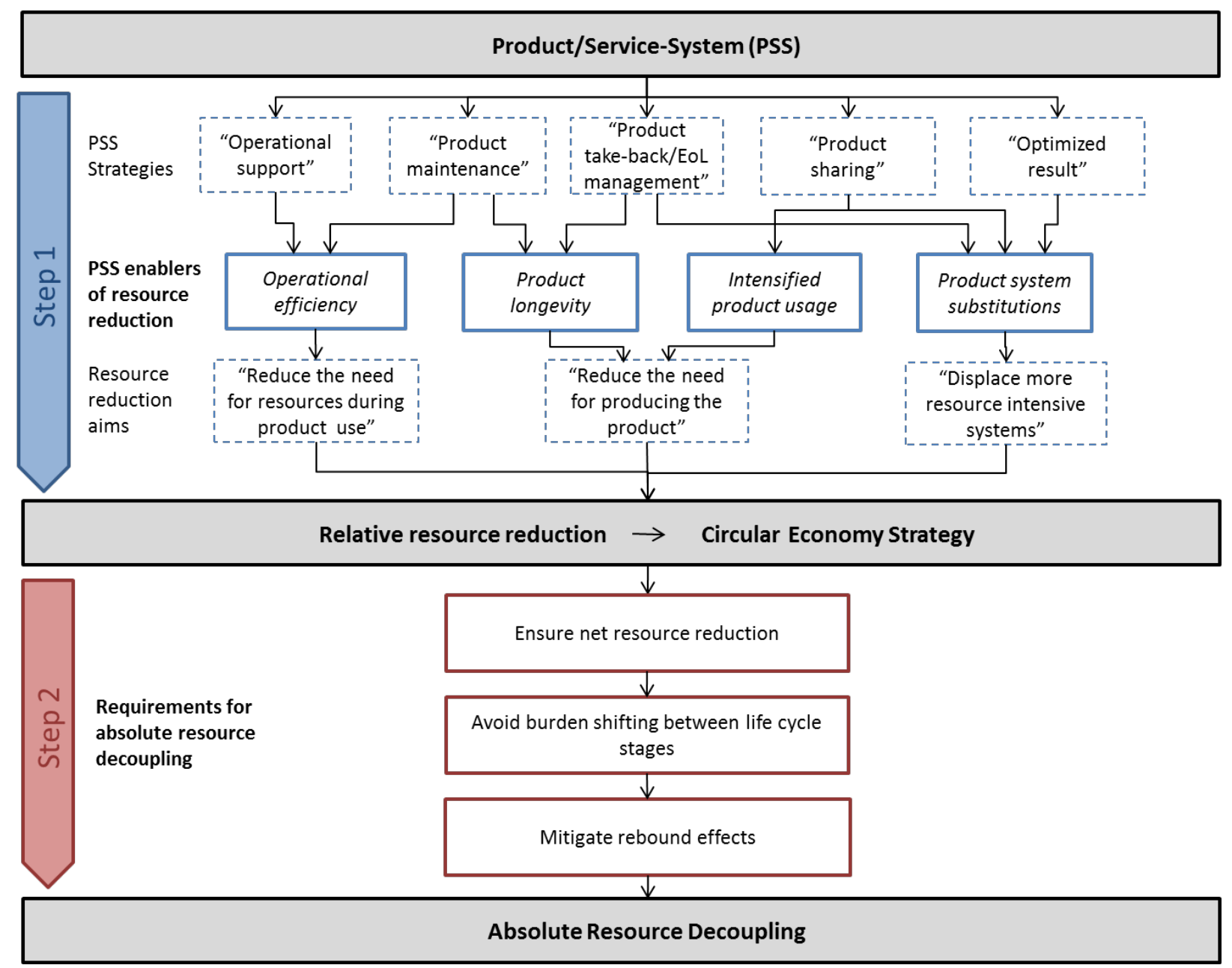

Figure 1: A two-step framework from PSS to Circular Economy strategy to absolute resource decoupling.

\section{<heading level 2> PSS strategies}

Five PSS strategies were identified through the literature review. The references presented are categorized as follows: A: Review paper; B: Conceptual publication; C: Case study.

- “Operational support”: The PSS provider supports the product operation, e.g. through performance monitoring or training of customer personnel. (Bocken et al. 2014 (A); Bartolomeo et al. 2003 (B); Pagoropoulos et al. 2017 (C))

- "Product maintenance": The PSS provider maintains the product during use, e.g. through preventive maintenance, repair or upgrades. (Bocken et al. 2014 (A); Bartolomeo et al. 
Kjær, L. L., Pigosso, D. C. A., Niero, M., Bech, N. M., \& McAloone, T. C. (2018). Product/Service-Systems for a Circular Economy: The Route to Decoupling Economic Growth from Resource Consumption? Journal of Industrial Ecology. DOI : $10.1111 /$ jiec. 12747

2003 (B); Manzini and Vezzoli 2002 (C); Bennett and Graedel 2000 (C); Lindahl et al. $2014(\mathrm{C}))$

- "Product sharing": The PSS provider combines retained ownership (i.e. product rental) with sharing of resources amongst users. (Bartolomeo et al. 2003 (B); Firnkorn and Müller 2011 (C); Amaya et al. 2014 (C); Mont 2004 (C))

- “Take-back/EoL management”: The PSS provider is in charge of end-of-life (EoL) management and decides how products are reused, remanufactured, refurbished, recycled etc. (Bocken et al. 2014 (A); Bartolomeo et al. 2003 (B); Manzini and Vezzoli 2002 (C); Kerr and Ryan 2001 (C); Lindahl et al. 2014 (C))

- “Optimized result”: The PSS provider delivers a functional result and dematerializes the offering (e.g. substitute physical transport with videoconference services). (Bartolomeo et al. 2003 (B); Manzini and Vezzoli 2002 (C))

Table 1 summarizes the five PSS strategies and introduces how they can support four different PSS enablers of resource reduction (hereafter "PSS enablers"). Three out of the five PSS strategies can support more than one PSS enabler. A PSS might incorporate one or more PSS strategies (as when combining product sharing and different EoL strategies in a rental scheme, as exemplified in Allais and Gobert (2016)) and thereby also combine more than one PSS enabler. Each of the four PSS enablers is discussed in the following. 
Kjær, L. L., Pigosso, D. C. A., Niero, M., Bech, N. M., \& McAloone, T. C. (2018). Product/Service-Systems for a Circular Economy: The Route to Decoupling Economic Growth from Resource Consumption? J ournal of Industrial Ecology. DOI : $10.1111 /$ jiec. 12747

Table 1: PSS strategies supporting four different PSS enablers of resource reduction.

\begin{tabular}{|l|l|}
\hline $\begin{array}{l}\text { PSS strategy } \\
\text { [type of PSS] }\end{array}$ & PSS enabler of resource reduction \\
\hline $\begin{array}{l}\text { "Operational support" (e.g. performance monitoring, } \\
\text { training of customer personnel) } \\
\text { [Product-oriented, use-oriented, result-oriented] }\end{array}$ & (1) Operational efficiency \\
\hline \multirow{2}{*}{$\begin{array}{l}\text { "Product maintenance" (incl. repair, upgrades etc.) } \\
\text { [Product-oriented, use-oriented, result-oriented] }\end{array}$} & (1) Operational efficiency \\
\cline { 2 - 3 } $\begin{array}{l}\text { "Product sharing" } \\
\text { [Use-oriented, result-oriented] }\end{array}$ & (2) Product longevity \\
\hline $\begin{array}{l}\text { "Take-back/EoL management" (for re-use, re- } \\
\text { manufacturing, refurbishing, recycling etc.) } \\
\text { [Product-oriented, use-oriented, result-oriented] }\end{array}$ & (3) Intensified product usage \\
\cline { 2 - 3 } & (4) Product system substitutions \\
\hline $\begin{array}{l}\text { “Optimized result" (e.g. substitute physical transport with } \\
\text { videoconference services) } \\
\text { [Result-oriented ] }\end{array}$ & (2) Product longevity \\
\cline { 2 - 3 } & (4) Product system substitutions \\
\hline
\end{tabular}

\section{<heading level 2> PSS enabler: Operational efficiency}

Operational efficiency is particularly relevant for product categories that are resource intensive during the use stage. Especially for energy-consuming products with long life cycles (washing machines, tumble driers, weaving machinery, irons, etc.), the use stage typically dominates in terms of resource consumption (Nordic Council of Ministers 1997; WRAP 2010). For these products, correct maintenance and efficient operation can lead to significant reduction of the overall amount of consumed resources, e.g. a shift of the spin speed of a dryer from $1200 \mathrm{rpm}$ to $1500 \mathrm{rpm}$ could result in savings of $0.3 \mathrm{kWh}$ per cycle (DEFRA 2009).

PSS that incorporate operational efficiency have the potential to minimize resource consumption during the use stage by supporting the user to lower the demand for energy and materials. Operational efficiency can be embedded in all three types of PSS:

- Product-oriented: the PSS provider sells the product and supplement with after-sales services such as consultancy services, user training, maintenance support and equipment upgrades; 
Kjær, L. L., Pigosso, D. C. A., Niero, M., Bech, N. M., \& McAloone, T. C. (2018). Product/Service-Systems for a Circular Economy: The Route to Decoupling Economic Growth from Resource Consumption? Journal of Industrial Ecology. DOI : $10.1111 /$ jiec. 12747

- Use-oriented: the PSS provider retains ownership of the product and is therefore usually responsible for maintaining the product and making sure that the product is operated efficiently;

- Result-oriented: the provider's responsibility is expanded to ensure that the product(s) needed to deliver the result are available. As the user pays for the results, the provider has incentives to ensure operational efficiency as it will directly increase their turnover by minimizing the resource consumption. Furthermore, activity-based consultancy offers may be directly linked to ensuring resource reduction as is known from ESCO agreements (focused on energy savings - Energy Savings COmpany) and MASCO agreements (focused on material savings - Materials Savings COmpany) (Anttonen 2010).

\section{<heading level 2> PSS enabler: Product longevity}

The fast turnover of products (mass consumption) has been highlighted as a resource-related problem for many product-groups including consumer electronics (Kalmykova et al. 2015) and clothing (Mair et al. 2014; Tojo et al. 2012) due to planned, technological and perceived obsolescence. Bakker et al. (2014) mapped the environmental impact of refrigerators and laptops and found that despite their increasing energy efficiency over time, product life extension (through longer product life, refurbishment and remanufacturing) is (currently) the preferred strategy.

PSS incorporating product longevity aim to support users to keep products in use longer, i.e. extending the use stage and thereby potentially minimizing resource consumption in the whole life cycle. All three types of PSS might incorporate product longevity:

- Product-oriented: after-sales services aiming to support correct maintenance, care taking, and potentially upgrading can enable not only operational efficiency, but also lead to the products staying in use for longer time, thereby prolonging their lifetime;

- Use-oriented: after-sales services might be intensified when the product is controlled and maintained by the provider. Furthermore, the provider has the opportunity to facilitate direct product reuse, e.g. through re-leasing schemes;

- Result-oriented: offers the biggest potential, as the customer pays for the service delivered (Tukker 2004). Product longevity would ensure that fewer products are needed to deliver the result, which would maximize the providers' profit. Similar to activity management/outsourcing (Tukker 2004), independent consultancy aimed at supporting product longevity can also be seen as a type of result-oriented PSS, where the service provider has no direct connection to the production of the products, but merely supports the user to keep products in use longer. 
Kjær, L. L., Pigosso, D. C. A., Niero, M., Bech, N. M., \& McAloone, T. C. (2018). Product/Service-Systems for a Circular Economy: The Route to Decoupling Economic Growth from Resource Consumption? Journal of Industrial Ecology. DOI : $10.1111 /$ jiec. 12747

\section{<heading level 2> PSS enabler: Intensified product usage}

Intensified product usage is enabled through product sharing. Sharing systems are classic within the PSS literature (e.g. Baines et al. 2007; Mont 2004) and the notion of the "sharing economy" is becoming more and more prevalent in the public debate (Gelbmann and Hammerl 2014; Madsen 2015), also in relation to CE (Ellen MacArthur Foundation 2015b). Product sharing is considered a sub-category of use-oriented PSS (Tukker 2004), but intensified product usage might also be utilized in a result-oriented PSS:

- Product-oriented: not relevant

- Use-oriented: Product sharing presents an opportunity to intensify the usage of products that are sub-utilized during their lifetime (Mont 2004). This can be products that are only used occasionally (e.g. garden equipment such as hedge trimmers or dresses for gala dinners) or are only in use for a short period (e.g. baby clothes). In these cases, renting the product in a use-oriented PSS setup may displace individual ownership, and thereby reduce the need for producing the product.

- Result-oriented: the PSS provider might choose to intensify the usage of the products needed to provide the result in order to exploit unutilized product capacity.

\section{<heading level 2> PSS enabler: Product system substitutions}

This enabler focuses on supporting product system substitutions. This can be considered at the PSS level, where shifts in the way the user fulfils the need is supported (e.g. substituting physical transport with videoconferences), or at the product level, where shared, reused products or recycled materials substitute other more resource intensive products (e.g. when a car sharing system utilizes electric cars). The enabler can be incorporated in all three types of PSS:

- Product-oriented: The PSS provider might offer an after-sales take-back service; enabling that product parts and materials can enter into new applications, where they substitute other products and materials.

- Use-oriented: Take-back options are even more profound, since product ownership stays with the PSS provider. A use-oriented PSS often change the way users fulfill their needs and thereby substitute other product systems during the use-stage. Shared products are often offered on a platform for users (e.g. a car-sharing system or digital music platform), where it displaces other types of product systems (e.g. public transport or CDs). For these cases ensuring that more resource-intensive systems are substituted can be challenging, since the provider usually has no or limited control over which users decide to use the system (Kjaer et al. 2016). 
Kjær, L. L., Pigosso, D. C. A., Niero, M., Bech, N. M., \& McAloone, T. C. (2018). Product/Service-Systems for a Circular Economy: The Route to Decoupling Economic Growth from Resource Consumption? Journal of Industrial Ecology. DOI : $10.1111 /$ jiec. 12747

- Result-oriented: the PSS provider has - in principle - the greatest control over the resources required to fulfill the user's need, which enables shifting the products and technologies used to deliver the result.

\section{<heading level 2> Resource reduction aims}

Three resource reduction aims are derived from the four PSS enablers (Figure 1). These are:

- "Reduce the need for resources during product use": the intention is to minimize the need for resources during product use through a direct influence in the use stage of the product life cycle. The PSS enabler is operational efficiency supported by the PSS strategies “operational support” and/or “product maintenance”.

- "Reduce the need for producing the product": the intention is indirectly to minimize resources usage during production and EoL stages of the product life cycle by increasing product utility in the use stage. The PSS enablers are: intensified product usage supported by the PSS strategy "product sharing", or product longevity supported by the PSS strategies "product maintenance” and/or “Take-back/EoL management” for direct reuse.

- "Displace more resource intensive systems": the intention is to direct the PSS or components of the PSS (products or materials) towards displacing alternative systems, products or materials in a way that enables a net resource reduction. The PSS enabler is product system substitution, supported by the PSS strategies "optimized result" and/or “Take-back/EoL management” and/or “product sharing”.

\section{<heading level 1> Framework step two: Requirements for absolute resource decoupling}

The limitations of CE and PSS, discussed in the introduction, were consolidated into three subsequent requirements for absolute resource decoupling: Ensure net resource reduction, avoid burden shifting between life cycle stages, and mitigate rebound effects (Figure 1). Each of the three is presented in the following.

\section{$<$ heading level 2> Ensure net resource reduction}

The primary requirement for a PSS to lead to absolute resource decoupling is that it actually enables net resource reduction. Ensuring that all relevant comparable alternatives (displaced systems) are included and that all relevant processes (inputs) are taken into account are crucial aspects when objectively evaluating the environmental performance of a PSS (Kjaer et al. 2016). This may be illustrated through a simple equation:

$$
\text { net resource reduction }=\text { avoided resources }- \text { induced resources }
$$


Kjær, L. L., Pigosso, D. C. A., Niero, M., Bech, N. M., \& McAloone, T. C. (2018). Product/Service-Systems for a Circular Economy: The Route to Decoupling Economic Growth from Resource Consumption? Journal of Industrial Ecology. DOI : $10.1111 /$ jiec. 12747

The resource reduction (and related environmental impact reduction) potential depends on the resources avoided in the displaced systems (also taking into account the displacement rate) and the induced (added/incurred) resources needed for offering the PSS. The principle is the same as shown by Zink and Geyer (2017) in the case of recycling: the environmental benefit is the difference between incurred impacts of reprocessing and avoided impacts of primary production.

The requirement "ensure net resource reduction" can be viewed from different perspectives for each aforementioned PSS enabler:

- Operational efficiency: the induced processes stemming from the service itself (e.g. increased consumption of monitoring equipment, spare parts and upgrades, added logistics and indirect resource consumption from the service administration) need to be accounted for and must not exceed the avoided resource consumption in the receiving system.

- Product longevity: it needs to be ensured that the same demand is in fact fulfilled using fewer resources, since the aim is to "reduce the need for producing the product". Factors such as technological and perceived obsolescence where products are discarded despite still being well-functioning (Ongondo and Williams 2011; Kalmykova et al. 2015) might counteract the intention of product life extension.

- Intensified product usage: it needs to be ensured that there is in fact an unexploited potential for sharing in the existing market and that customers will accept to share product utility as a displacement of individual ownership (in order to successfully "reduce the need for producing the product”).

- For product system substitutions, the aim of "displacing more resource intensive systems” should help meet the requirement of net resource reduction, as one needs to compare the PSS against the displaced systems, in order to conclude that the aim is supported. For example, when a PSS includes a take-back system, which enables "recycling", the resource reduction potential depends on what the recycled material displaces. This also applies for shared products that displace alternative products systems.

The net resource reduction can be improved by designing and supporting the PSS, in order to displace systems where most resources are avoided. Furthermore, since a PSS utilizes materials and products, it can be investigated how the PSS can be optimized through ecodesign (Salazar et al. 2014), in order to reduce the induced resources. 
Kjær, L. L., Pigosso, D. C. A., Niero, M., Bech, N. M., \& McAloone, T. C. (2018). Product/Service-Systems for a Circular Economy: The Route to Decoupling Economic Growth from Resource Consumption? Journal of Industrial Ecology. DOI : $10.1111 /$ jiec. 12747

<heading level 2> Avoid burden shifting between life cycle stages

Optimizing one life cycle stage might increase resource consumption in other life cycle stages. This is sometimes referred to as burden shifting between life cycle stages (Laurent et al. 2012). Avoiding burden shifting between life cycle stages is especially relevant for strategies aimed at supporting specific life cycle stages. As such, a PSS focused on operational efficiency might entail redesigning the product, essentially affecting the resource use during production and/or EoL, potentially resulting in burden shifting. Similarly, product longevity and intensified product usage often require better quality products designed for high durability. This may result in a higher resource demand per product produced and if this is the case, the increased durability needs to make up for the increased upstream resource consumption. Also, for energy-consuming products, extending product life cycles directly or through reuse and remanufacturing is not necessarily better, as remanufactured products might be less energy efficient than new product generations (Gutowski et al. 2011). To support this, Bakker et al. (2014, p. 12) defined the "optimal product lifespan” as "the point in time where the environmental impacts that arise from using a product equal the embedded impacts of a (more energy efficient) replacement product." What these examples have in common is that the total resource use in a life cycle perspective, as well as external drivers that might affect the individual life cycle stages, need to be taken into account when evaluating and designing a PSS. In order to deal with the inherent complexity of the design task, several PSS design guidelines and tools have been developed over recent years (Tukker and Tischner 2006a; Manzini and Vezzoli 2002; Ceschin 2014; Chen et al. 2015; Bey and McAloone 2006; Morelli 2006; Pigosso and McAloone 2016), aiming to support the development of sustainable PSS.

\section{$<$ heading level 3> Mitigate rebound effects}

All four PSS enablers ultimately aim to reduce the amount of resources required to fulfil users' needs. Thus, they have the potential to lead to resource decoupling in relative terms, however not necessarily in absolute terms. Absolute resource decoupling can only be ensured when taking into account so-called "rebound effects”.

Rebound effects occur when a product is offered at a lower price, which is often the case with shared, reused or recycled products. The saved money will be spent on alternative consumption, which requires additional resources (Fumikazu et al. 2001; Oberender and Birkhofer 2004; Scheepens et al. 2016). Furthermore, rebound effects are not only caused by changes in price, but in principle by all constraints that are affected by the utility-level of a product (Hofstetter and Madjar, 2003 apud Vivanco and Voet, 2014). Rebound effects may be defined as "the derived changes in production and consumption when the implementation of an improvement option liberates or binds 
Kjær, L. L., Pigosso, D. C. A., Niero, M., Bech, N. M., \& McAloone, T. C. (2018). Product/Service-Systems for a Circular Economy: The Route to Decoupling Economic Growth from Resource Consumption? Journal of Industrial Ecology. DOI : $10.1111 /$ jiec. 12747

a scarce production or consumption factor" (Weidema et al. 2009, p. 23). In an even broader understanding, a rebound effect occurs when the actual resource reduction from an improvement is less than expected because of behavioral or systemic responses. Adapted user behavior is a common cause of rebound effects, e.g. when a more fuel efficient car incentivizes users to drive more.

Whereas rebound effects may be difficult to avoid completely, eco-efficient value creation (Scheepens et al. 2016) has been proposed as a mean to mitigate them. Eco-efficient value creation is the process of designing value-adding activities, which positively influence the customer's perceived value, resulting in a higher "Willingness To Pay" for resource-efficient solutions, essentially mitigating the economic rebound effect (Scheepens et al. 2016). The strategy could thus be to ensure that the overall economic spending on needs fulfilment is not decreasing.

A PSS may have the advantage that saved money stemming from reduced resource consumption is at least partly spent on the services (e.g. consultancy). Provided that the money spent on consultancy equates to or exceeds the amount of money saved from buying fewer products, the economic rebound effect could be partly mitigated, since more service-intensive uses typically have lower impacts per money spent than product-intensive uses (Kjaer et al. 2015).

However, rebound effects will often occur as a result of mechanisms outside the direct control of the PSS provider. Especially structural rebound effects (systemic market response to changes in aggregated total demand) and transformational rebound effects (systemic societal response to changes in e.g. consumers' preferences or social institutions) (Vivanco and Voet 2014) can be difficult to mitigate. Furthermore, the above proposals only target the economic rebound effects. Adapted user behavior caused by changes in other consumption factors such as changes in time or space are not accounted for.

\section{$<$ heading level 1> Application of the framework}

The framework is applied as follows:

1. Understand how the PSS leads to a CE strategy

a. Identify the PSS enablers of resource reduction and the resource reduction aims.

b. Describe the conditions for the enablers and aims.

2. Understand how the CE strategy leads to absolute resource decoupling

a. Check under which circumstances the requirements for absolute resource decoupling are fulfilled.

b. Describe the potential limitations of the PSS to fulfil the requirements.

In order to exemplify the application of the proposed framework when analyzing PSS solutions, we present illustrative cases of PSS in the Danish textile industry, obtained by means of a literature 
Kjær, L. L., Pigosso, D. C. A., Niero, M., Bech, N. M., \& McAloone, T. C. (2018). Product/Service-Systems for a Circular Economy: The Route to Decoupling Economic Growth from Resource Consumption? Journal of Industrial Ecology. DOI : $10.1111 /$ jiec. 12747

review. The cases are exemplary and were selected based on their potential to allow an enhanced understanding of the defined PSS enablers and the requirements for absolute resource decoupling.

We chose the textile industry due to its potential to transition towards CE (Ellen MacArthur Foundation 2013). Many textile products such as clothing have short life cycles and depending on the type of fibers, textile production consumes high amounts of energy and water, and results in significant greenhouse gas emissions (Business for Social Responsibility 2009). In addition, resources are consumed due to the need for laundering, during the use stage. Clothing PSS such as take-back systems, swaps and subscriptions may provide the industry with a mechanism to increase factors such as product quality and longevity (Armstrong et al. 2015).

In this paper, the proposed framework is intended for generic use and the principles apply to both business-to-business (B2B) and business-to-consumer (B2C) relationships. For each illustrative case, the user segment will be stated.

\section{<heading level 2> Laundry-service (vs. home-washing) (B2C)}

For many everyday textiles, laundering in the use stage represents the most resource-intensive process throughout the product life cycle (Business for Social Responsibility 2009). Professional laundry-service companies offer a result-oriented business model, where customers pay for clean, dry textiles and the logistics associated with collection and delivery. Among others, the Danish company Washa (Washa 2016) provides such a service. Due to economies-of-scale, there is a potential for a professional laundry service to increase resource efficiency of the washing process, compared to traditional home-washing (Heiskanen and Jalas 2003). The framework elements are discussed in Table 2.

Table 2: Laundry-service (vs. home-washing)

\begin{tabular}{|c|c|c|}
\hline PSS type & Result-oriented & \\
\hline User segment & B2C & \\
\hline \multicolumn{3}{|c|}{ PSS $\rightarrow$ CE strategy } \\
\hline & & Conditions \\
\hline $\begin{array}{l}\text { PSS enabler of resource } \\
\text { reduction }\end{array}$ & Operational efficiency & $\begin{array}{l}\text { The PSS enables operational efficiency } \\
\text { during the process from dirty to clean } \\
\text { textiles. }\end{array}$ \\
\hline Resource reduction aim & $\begin{array}{l}\text { "Reduce the need for resources during } \\
\text { use" }\end{array}$ & $\begin{array}{l}\text { The aim should be to reduce the resources } \\
\text { used for laundering the textiles in the use- } \\
\text { stage. }\end{array}$ \\
\hline \multicolumn{3}{|c|}{ CE strategy $\rightarrow$ absolute resource decoupling } \\
\hline & Requirement is fulfilled, when... & Limitations \\
\hline $\begin{array}{l}\text { Ensure net resource } \\
\text { reduction }\end{array}$ & $\begin{array}{l}\text {...resources needed during the process } \\
\text { from dirty to clean textiles in households } \\
\text { (without the PSS) } \\
>\text { (are higher than) }\end{array}$ & $\begin{array}{l}\text { Requirement fulfilment depends on how } \\
\text { the laundry was previously done at the } \\
\text { household (e.g. if it included tumble- } \\
\text { drying) and how the PSS is designed, }\end{array}$ \\
\hline
\end{tabular}


Kjær, L. L., Pigosso, D. C. A., Niero, M., Bech, N. M., \& McAloone, T. C. (2018). Product/Service-Systems for a Circular Economy: The Route to Decoupling Economic Growth from Resource Consumption? Journal of Industrial Ecology. DOI : $10.1111 /$ jiec. 12747

\begin{tabular}{|c|c|c|}
\hline & $\begin{array}{l}\text { Resources needed during the process } \\
\text { from dirty to clean textiles in PSS } \\
\text { (including transport/infrastructure, } \\
\text { washing, drying etc.) }\end{array}$ & $\begin{array}{l}\text { including how the textiles are transported } \\
\text { (the infrastructure) and the type of energy } \\
\text { used at the washing facility. As such, } \\
\text { induced processes such as transport needed } \\
\text { for collection and delivery as well as } \\
\text { increased tumble drying have to be } \\
\text { accounted for (Heiskanen and Jalas 2003). } \\
\text { Furthermore, the displacement rate might } \\
\text { not be } 1: 1 \text { and some PSS users might still } \\
\text { do some of their laundry at home in } \\
\text { addition to the laundry service. }\end{array}$ \\
\hline $\begin{array}{l}\text { Avoid burden shifting } \\
\text { between life cycle stages }\end{array}$ & ...the textiles' durability is not affected & $\begin{array}{l}\text { Going from home-washing to a laundry- } \\
\text { service might introduce burden shifting } \\
\text { between life cycle stages of the textiles. It } \\
\text { needs to be ensured that e.g. increased use } \\
\text { of automated drying is not resulting in } \\
\text { increased abrasion of the textiles, } \\
\text { potentially resulting in decreased durability } \\
\text { (textiles needs to be discarded more often). }\end{array}$ \\
\hline Mitigate rebound effects & $\begin{array}{l}\text {...the laundering frequency is not } \\
\text { affected and value-adding low-resource } \\
\text { intensive services mitigate or exceed any } \\
\text { potential costs-savings }\end{array}$ & $\begin{array}{l}\text { A direct rebound effect occurs if the users } \\
\text { start to have their laundry done more often } \\
\text { as a result of increased convenience and } \\
\text { time saved. Indirect rebound effects occur } \\
\text { if users save money by using the service } \\
\text { compared to paying for a washing machine, } \\
\text { water, electricity etc. at home. It should be } \\
\text { noted, that the contrary might also be the } \\
\text { case if the service is more expensive for the } \\
\text { user. In this case, the rebound effect would } \\
\text { be "negative" (which would mean a } \\
\text { positive result in terms of resource } \\
\text { reduction). }\end{array}$ \\
\hline
\end{tabular}

<heading level 2> Subscription to children's clothing (B2C)

Small children usually outgrow their clothes before they are worn out. Unless the clothes are passed on to siblings or others, this results in premature disposal and an unutilized potential for product sharing or reuse. The Danish company Vigga (Vigga 2016) offers subscriptions to high quality children's clothing based on a use-oriented business model. As the child grows, items are replaced with new clothing. Clothing is returned to Vigga where it is laundered and subsequently reused by a new subscriber. The framework elements are discussed in Table 3. 
Kjær, L. L., Pigosso, D. C. A., Niero, M., Bech, N. M., \& McAloone, T. C. (2018). Product/Service-Systems for a Circular Economy: The Route to Decoupling Economic Growth from Resource Consumption? Journal of Industrial Ecology. DOI : $10.1111 /$ jiec. 12747

Table 3: Subscription to children’s clothing

\begin{tabular}{|c|c|c|}
\hline PSS type & Use-oriented & \\
\hline User segment & B2C & \\
\hline \multicolumn{3}{|c|}{ PSS $\rightarrow$ CE strategy } \\
\hline & & Conditions \\
\hline $\begin{array}{l}\text { PSS enabler of resource } \\
\text { reduction }\end{array}$ & Product longevity & $\begin{array}{l}\text { The PSS enables product longevity by } \\
\text { avoiding premature disposal (when the } \\
\text { clothes are disposed of after initial use). }\end{array}$ \\
\hline $\begin{array}{l}\text { PSS enabler of resource } \\
\text { reduction }\end{array}$ & Intensified product usage & $\begin{array}{l}\text { The PSS enables intensified product usage } \\
\text { by avoiding unutilized capacity (when after } \\
\text { use, the clothes are stored in e.g. a closet). }\end{array}$ \\
\hline Resource reduction aim & $\begin{array}{l}\text { "Reduce the need for producing the } \\
\text { product" }\end{array}$ & $\begin{array}{l}\text { The aim should be to reduce the production } \\
\text { of new garments through displacement of } \\
\text { individual single-use ownership. }\end{array}$ \\
\hline \multicolumn{3}{|c|}{ CE strategy $\rightarrow$ absolute resource decoupling } \\
\hline & Requirement is fulfilled, when... & Limitations \\
\hline $\begin{array}{l}\text { Ensure net resource } \\
\text { reduction }\end{array}$ & $\begin{array}{l}\text {...resources needed for needs fulfillment } \\
\text { (e.g. clothing of child from } 0 \text { to } 2 \text { years) } \\
\text { without Vigga subscription } \\
\text { >(are higher than) } \\
\text { Resources needed for needs fulfillment } \\
\text { (e.g. clothing of child from } 0 \text { to } 2 \text { years) } \\
\text { with Vigga subscription }\end{array}$ & $\begin{array}{l}\text { The displacement of resources might be } \\
\text { lower than expected due to the fact that } \\
\text { children's garments already circulate in and } \\
\text { between households through informal } \\
\text { channels. This is often left out in statistics, } \\
\text { but needs to be taken into account when } \\
\text { assessing the potentials of reuse schemes } \\
\text { (Laitala and Klepp 2015; Madsen 2015). } \\
\text { Also induced resources stemming from } \\
\text { logistics and supporting IT platform should } \\
\text { be accounted for in the PSS to ensure net } \\
\text { resource reduction. }\end{array}$ \\
\hline $\begin{array}{l}\text { Avoid burden shifting } \\
\text { between life cycle stages }\end{array}$ & $\begin{array}{l}\text {...additional resources are not required } \\
\text { during production and end-of-life }\end{array}$ & $\begin{array}{l}\text { The clothes need to be designed for high } \\
\text { durability. However, since product design } \\
\text { is part of the Vigga concept, careful } \\
\text { selection of materials and production } \\
\text { methods could help avoid burden shifting. }\end{array}$ \\
\hline Mitigate rebound effects & $\begin{array}{l}\text {...value-adding low-resource intensive } \\
\text { services mitigate or exceed any potential } \\
\text { costs-savings }\end{array}$ & $\begin{array}{l}\text { Requirement fulfilment depends on } \\
\text { whether users save or spend more money as } \\
\text { a result of subscribing to the service. } \\
\text { Other changes in user behavior than what is } \\
\text { captured here might trigger rebound effects } \\
\text { (e.g. if users save space in closets, they } \\
\text { might consume more of other products). }\end{array}$ \\
\hline
\end{tabular}

$<$ heading level 2> Leasing of textiles in the healthcare sector (B2B)

In a recent publication, EMF has assessed the circular potential for a number of Danish sectors including healthcare (Ellen MacArthur Foundation 2015b). According to the publication, leasing of clean textiles represents the most widely adopted performance-based business model in the Danish healthcare sector. The business model is a result-oriented PSS that provides textiles, laundry-service and associated logistics, which in principal means that all of the four PSS enablers (see Table 1) may be utilized. However, in this example, we focus on the potential product system substitution in the EoL stage. Due to the fact that the PSS provider retains ownership of the textiles, they also have 
Kjær, L. L., Pigosso, D. C. A., Niero, M., Bech, N. M., \& McAloone, T. C. (2018). Product/Service-Systems for a Circular Economy: The Route to Decoupling Economic Growth from Resource Consumption? Journal of Industrial Ecology. DOI : $10.1111 /$ jiec. 12747

the option to plan for EoL strategies. Garments from the hospitals can be reused or recycled into new applications and thereby displace alternative production of raw materials. The Danish company, De Forenede Dampvaskerier (DFD), caters for a number of Danish hospitals and due to economies-of-scale, the PSS provider can guarantee a large volume of homogenous textiles. This entails that EoL strategies may become profitable as an alternative to pay for waste handling fees. DFD is exploring this potential in collaboration with designers, and currently one EoL strategy is to reprocess worn-out work clothes into construction materials and furniture (De Forenede Dampvaskerier 2017). The framework elements are discussed in Table 4.

Table 4: Leasing of textiles in the healthcare sector

\begin{tabular}{|c|c|c|}
\hline PSS business model & Result-oriented & \\
\hline PSS type & B2B & \\
\hline \multicolumn{3}{|c|}{ PSS $\rightarrow$ CE strategy } \\
\hline & & Conditions \\
\hline $\begin{array}{l}\text { PSS enabler of resource } \\
\text { reduction }\end{array}$ & Product system substitutions & $\begin{array}{l}\text { The PSS provider retains ownership of the } \\
\text { textiles, and at EoL the textiles are recycled } \\
\text { into new applications, thereby substituting } \\
\text { different product systems (in this case } \\
\text { construction materials and furniture). }\end{array}$ \\
\hline Resource reduction aim & $\begin{array}{l}\text { "Displace more resource intensive } \\
\text { systems" }\end{array}$ & $\begin{array}{l}\text { The aim should be to decrease resource } \\
\text { usage in the displaced products/materials. }\end{array}$ \\
\hline \multicolumn{3}{|c|}{ CE strategy $\rightarrow$ absolute resource decoupling } \\
\hline & Requirement is fulfilled, when... & Limitations \\
\hline $\begin{array}{l}\text { Ensure net resource } \\
\text { reduction }\end{array}$ & $\begin{array}{l}\text {...resources displaced by the recycled } \\
\text { textiles } \\
>\text { (are higher than) } \\
\text { Resources needed for reprocessing }\end{array}$ & $\begin{array}{l}\text { When recycling the textiles into } \\
\text { construction materials and furniture, } \\
\text { requirement fulfilment depends on the } \\
\text { alternative materials and manufacturing } \\
\text { process for these products as well as the } \\
\text { resources needed for reprocessing the } \\
\text { textiles. }\end{array}$ \\
\hline $\begin{array}{l}\text { Avoid burden shifting } \\
\text { between life cycle stages }\end{array}$ & $\begin{array}{l}\text {...the textiles' durability is not affected } \\
\text { by “design for EoL” requirements. }\end{array}$ & $\begin{array}{l}\text { The capability to reprocess the textiles into } \\
\text { new applications might require that certain } \\
\text { conditions are in place, which affects the } \\
\text { other life cycle stages. For example, in } \\
\text { order to ensure pure fractions, the textiles } \\
\text { need to be designed in homogeneous } \\
\text { material, which might affect the durability } \\
\text { and shorten the product lifespan. }\end{array}$ \\
\hline Mitigate rebound effects & $\begin{array}{l}\text {...the reprocessed materials/products are } \\
\text { of high enough quality to compete } \\
\text { directly with their substitutes. }\end{array}$ & $\begin{array}{l}\text { Offering the reprocessed material/product } \\
\text { at a lower prize or targeting niche markets } \\
\text { will inevitably trigger rebound effects } \\
\text { (Zink and Geyer 2017) }\end{array}$ \\
\hline
\end{tabular}

\section{<heading level $1>$ Concluding remarks}

In this forum paper, we have highlighted the gap between the common CE proposed business action "offering products as a service" and the claimed CE goal of resource decoupling, by asking: Are PSS for a Circular Economy the route to decoupling economic growth from resource 
Kjær, L. L., Pigosso, D. C. A., Niero, M., Bech, N. M., \& McAloone, T. C. (2018). Product/Service-Systems for a Circular Economy: The Route to Decoupling Economic Growth from Resource Consumption? Journal of Industrial Ecology. DOI : $10.1111 /$ jiec. 12747

consumption? Our main errand with this paper has been to challenge the research communities connected to Industrial Ecology and CE to be more critical, when proposing PSS as means to realizing a CE. Our position is that the ultimate aim of CE should be to enable absolute resource decoupling, which goes beyond simply extracting more value from resources. Our vehicle for discussion has been the proposed two-step framework that links PSS to CE Strategies in the first instance, and subsequently CE Strategies to absolute resource decoupling. In the first step of the framework we propose four PSS enablers of resource reduction, linking PSS strategies to resource reduction aims to qualify it as a CE strategy. Secondly, the framework proposes three subsequent requirements for absolute resource decoupling: ensure net resource reduction, avoid burden shifting between life cycle stages and mitigate rebound effects. These requirements are not usually considered when proposing a PSS, which potentially leads to sub-optimized solutions from an environmental point of view. The requirements can also be used as a checklist to avoid claims that CE strategies are intrinsically more environmentally sustainable than linear models. As such, the proposed analytical framework is a first step towards consolidating an approach for companies and institutions to critically analyze alternative PSS strategies and support their refinement towards absolute resource decoupling. The framework was demonstrated by analyzing PSS cases within the Danish textile industry. The case analyses showed the conditions that needed to be in place for the PSS to enable relative resource reduction and exemplified limitations for achieving absolute resource decoupling. However, further work is needed to make the framework operational in a business context. Enhancement of the proposed framework should be based on a combination of theory-driven (e.g. by means of an enhanced systematic literature review) and empirical-driven (e.g. evaluation by experts and case studies) strategies. The proposed framework is currently being used in connection with the development of guidelines to support objective evaluations of the environmental performance of PSS.

With the aim of stimulating discussion and further dialogue in both academia and in industry, regarding the role of PSS in a CE, we invite other scholars to critique and enhance the proposed framework. To that end, we propose the following questions: a) In what ways could the two-steplogic of the analytical framework be further enhanced? b) What would be the best way to test the comprehensiveness of the enablers and requirements, as well as the relationships between these? c) How can rebound effects triggered by customer behavior, market mechanisms, legislation, technical developments, and other circumstances not directly influenced by the providing company be addressed in the formulation and realization of circular economy strategies in the context of PSS? d) How can the overall feasibility of a "closed loop economy" and absolute resource decoupling be further assessed? 
Kjær, L. L., Pigosso, D. C. A., Niero, M., Bech, N. M., \& McAloone, T. C. (2018). Product/Service-Systems for a Circular Economy: The Route to Decoupling Economic Growth from Resource Consumption? Journal of Industrial Ecology. DOI : $10.1111 /$ jiec. 12747

A key message in this paper is that investigating the resource decoupling potential of PSS requires a system perspective and a life cycle approach. It needs to be ensured that the PSS is designed in a way that the provider can add value and create a turnover through service offerings, whilst also reducing the overall need for resources. As such, the most important strengths of enabling CE strategies through a PSS are 1) the ability to direct and control the use of resources and 2) the ability to design and implement service-intensive and value-adding offerings, essentially dematerializing the need fulfillment and influencing user behavior. However, as long as these types of offerings are driven by ensuring economic growth alone, and not by reduced production and consumption, the proposed resource reduction aims and the requirements for absolute resource decoupling will have a difficult time being fulfilled. It is imperative that the balance of production, consumption and wellbeing is addressed as a key goal for societies and the individuals and businesses within them to be able to thrive through absolute resource decoupling.

\section{$<$ heading level 1> Acknowledgements}

We would like to express our deepest gratitude to the editors and reviewers for their valuable suggestions to improve the readability and scientific value of this paper. This work was funded by the TORM foundation and supported by the Carlsberg Foundation through the project "Absolute Circular Economy” (ACE) toolkit.

\section{$<$ heading level 1 $>$ References}

Agrawal, V. V., M. Ferguson, L.B. Toktay, and V.M. Thomas. 2012. Is Leasing Greener Than Selling? Management Science 58(3): 523-533.

Allais, R. and J. Gobert. 2016. A multidisciplinary method for sustainability assessment of PSS: Challenges and developments. CIRP Journal of Manufacturing Science and Technology 15: 56-64.

Amaya, J., A. Lelah, and P. Zwolinski. 2014. Design for intensified use in product-service systems using life-cycle analysis. Journal of Engineering Design 25(7-9): 280-302.

Andersen, M.S. 2007. An introductory note on the environmental economics of the circular economy. Sustainability Science 2(1): 133-140.

Anttonen, M. 2010. Greening from the Front to the Back Door? A Typology of Chemical and Resource Management Services. Business strategy and the Environment 19(3): 199-215.

Armstrong, C.M., K. Niinimäki, S. Kujala, E. Karell, and C. Lang. 2015. Sustainable productservice systems for clothing: exploring consumer perceptions of consumption alternatives in 
Kjær, L. L., Pigosso, D. C. A., Niero, M., Bech, N. M., \& McAloone, T. C. (2018). Product/Service-Systems for a Circular Economy: The Route to Decoupling Economic Growth from Resource Consumption? Journal of Industrial Ecology. DOI : $10.1111 /$ jiec. 12747

Finland. Journal of Cleaner Production 97: 30-39.

Bakker, C., F. Wang, J. Huisman, and M. den Hollander. 2014. Products that go round: exploring product life extension through design. Journal of Cleaner Production 69: 10-16.

Bartolomeo, M., D. Dal Maso, P. De Jong, P. Eder, P. Groenewegen, P. Hopkinson, P. James, et al. 2003. Eco-efficient producer services - What are they, how do they benefit customers and the environment and how likely are they to develop and be extensively utilised? Journal of Cleaner Production 11: 829-837.

Bennett, E.B. and T.E. Graedel. 2000. 'Conditioned Air’: Evaluating an Environmentally Preferable Service. Environmental Science \& Technology 34(4): 541-545.

Benyus, J. 2002. Biomimicry: Innovation Inspired by Nature. New York: HarperCollins.

Bey, N. and T.C. Mcaloone. 2006. From LCA to PSS - Making leaps towards sustainability by applying product/service-system thinking in product development. In 13th CIRP International Conference on Life Cycle Engineering, 571-576.

Bilitewski, B. 2012. The Circular Economy and its Risks. Waste Management 32(1): 1-2.

Blomsma, F. and G. Brennan. 2017. The emergence of circular economy: a new framing around prolonging resource productivity. Journal of Industrial Ecology 21(3): 603-614.

Bocken, N.M.P., E.A. Olivetti, J.M. Cullen, J. Potting, and R. Lifset. 2017. Taking the Circularity to the Next Level: A Special Issue on the Circular Economy. Journal of Industrial Ecology 21(3): 476-482.

Bocken, N.M.P., S.W. Short, P. Rana, and S. Evans. 2014. A literature and practice review to develop sustainable business model archetypes. Journal of Cleaner Production 65: 42-56.

Braungart, M., W. McDonough, and A. Bollinger. 2007. Cradle-to-cradle design: creating healthy emissions - a strategy for eco-effective product and system design. Journal of Cleaner Production 15(13-14): 1337-1348.

Business for Social Responsibility. 2009. Apparel Industry Life Cycle Carbon Mapping Prepared by Business for Social Responsibility. https://www.bsr.org/reports/BSR_Apparel_Supply_Chain_Carbon_Report.pdf.

Ceschin, F. 2014. Sustainable Product-Service Systems: Between Strategic Design and Transition Studies. 1st ed. Springer.

Chen, D., X. Chu, X. Yang, X. Sun, Y. Li, and Y. Su. 2015. PSS solution evaluation considering sustainability under hybrid uncertain environments. Expert Systems with Applications 42(14): 5822-5838.

Dahmus, J.B. and T.G. Gutowski. 2011. Can Efficiency Improvements Reduce Resource Consumption? A Historical Analysis of Ten Activities. Journal of Industrial Ecology 18(6): 
Kjær, L. L., Pigosso, D. C. A., Niero, M., Bech, N. M., \& McAloone, T. C. (2018). Product/Service-Systems for a Circular Economy: The Route to Decoupling Economic Growth from Resource Consumption? Journal of Industrial Ecology. DOI : $10.1111 /$ jiec. 12747

883-897.

DEFRA. 2009. Reducing the environmental impact of clothes cleaning.

EC (European Commission). 2015. Closing the loop - An EU action plan for the Circular Economy. Brussels. http://ec.europa.eu/environment/circular-economy/index_en.htm.

Ellen MacArthur Foundation. 2013. Towards the Circular Economy: Opportunities for the consumer goods sector.

https://www.ellenmacarthurfoundation.org/assets/downloads/publications/TCE_Report2013.pdf.

Ellen MacArthur Foundation. 2015a. Growth within: A circular economy vision for a competitive europe.

https://www.ellenmacarthurfoundation.org/assets/downloads/publications/EllenMacArthurFou ndation_Growth-Within_July15.pdf.

Ellen MacArthur Foundation. 2015b. DELIVERING THE CIRCULAR ECONOMY - A TOOLKIT FOR POLICYMAKERS.

https://www.ellenmacarthurfoundation.org/assets/downloads/publications/EllenMacArthurFou ndation_PolicymakerToolkit.pdf.

Firnkorn, J.J. and M. Müller. 2011. What will be the environmental effects of new free-floating carsharing systems? The case of car2go in Ulm. Ecological Economics 70(8): 1519-1528.

Forenede Dampvaskerier, De. 2017. DFD Selvfølgelig cirkulær økonomi [DFD Selvfølgelig circular economy]. http://www.dfd.dk/loesninger/velfaerd-og-sundhed/selvfoelgelig/cirkulaerokonomi. Accessed June 2, 2017.

Fumikazu, M., K. Satsuki, I. Naoki, K. Kengo, S. Rei, Y. Kenji, W. Satoko, et al. 2001. Eco-Value as an Indicator for Sustainable Design. In Proceedings EcoDesign 2001: Second International Symposium on Environmentally Conscious Design and Inverse Manufacturing, 1106-1109. Tokyo: IEEE.

Geissdoerfer, M., P. Savaget, N.M.P. Bocken, and E.J. Hultink. 2017. The Circular Economy - A new sustainability paradigm? Journal of Cleaner Production 143: 757-768.

Gelbmann, U. and B. Hammerl. 2014. Integrative re-use systems as innovative business models for devising sustainable product-service-systems. Journal of Cleaner Production 97(2015): 50-60.

Ghisellini, P., C. Cialani, and S. Ulgiati. 2016. A review on circular economy: The expected transition to a balanced interplay of environmental and economic systems. Journal of Cleaner Production 114: 11-32.

Goedkoop, M.J., C.J.G. van Halen, H.R.M. te Riele, and P.J.M. Rommens. 1999. Product service systems, ecological and economic basics. Report for Dutch Ministries of Environment (VROM) 
Kjær, L. L., Pigosso, D. C. A., Niero, M., Bech, N. M., \& McAloone, T. C. (2018). Product/Service-Systems for a Circular Economy: The Route to Decoupling Economic Growth from Resource Consumption? Journal of Industrial Ecology. DOI : $10.1111 /$ jiec. 12747

and Economic Affairs (EZ). Amersfoort, The Netherlands.

Grosso, M., M. Niero, and L. Rigamonti. 2017. Circular economy, permanent materials and limitations to recycling: Where do we stand and what is the way forward? Waste Management and Research 35(8).

Gutowski, T.G., S. Sahni, A. Boustani, and S.C. Graves. 2011. Remanufacturing and energy savings. Environmental Science \& Technology 45(10): 4540-7.

Haupt, M. and M. Zschokke. 2017. How can LCA support the circular economy?_63rd discussion forum on life cycle assessment, Zurich, Switzerland, November 30, 2016. International Journal of Life Cycle Assessment 22(5): 832-837.

Heiskanen, E. and M. Jalas. 2003. Can services lead to radical eco-efficiency improvements? - a review of the debate and evidence. Corporate Social Responsibility and Environmental Management 10(4): 186-198.

Hofstetter, P. and M. Madjar. 2003. Linking change in happiness, time-use, sustainable consumption, and environmental impacts; An attempt to understand time-rebound effects. Final Report to the Society for Non-Traditional Technology. Zurich.

Haase, R.P., D.C.A. Pigosso, and T.C. McAloone. 2017. Product/Service-System Origins and Trajectories: A Systematic Literature Review of PSS Definitions and their Characteristics. Procedia CIRP 64: 157-162.

Jackson, T. 2009. Prosperity Without Growth: Economics for a Finite Planet. Ed. by Earthscan. London.

Kalmykova, Y., J. Patrício, L. Rosado, and P.E.O. Berg. 2015. Out with the old, out with the new The effect of transitions in TVs and monitors technology on consumption and WEEE generation in Sweden 1996-2014. Waste Management 46: 511-522.

Kerr, W. and C. Ryan. 2001. Eco-efficiency gains from remanufacturing: A case study of photocopier remanufacturing at Fuji Xerox Australia. Journal of Cleaner Production 9: 75-81. Kirchherr, J., D. Reike, and M. Hekkert. 2017. Conceptualizing the Circular Economy: An Analysis of 114 Definitions. Resources, Conservation and Recycling 127: 221-232.

Kjaer, L., N. Høst-Madsen, J. Schmidt, and T. McAloone. 2015. Application of Environmental Input-Output Analysis for Corporate and Product Environmental Footprints-Learnings from Three Cases. Sustainability 7(9): 11438-11461.

Kjaer, L.L., A. Pagoropoulos, J.H. Schmidt, and T.C. McAloone. 2016. Challenges when evaluating Product/Service-Systems through Life Cycle Assessment. Journal of Cleaner Production 122: 95-104

Korhonen, J., A. Honkasalo, and J. Seppälä. 2018. Circular Economy: The Concept and its 
Kjær, L. L., Pigosso, D. C. A., Niero, M., Bech, N. M., \& McAloone, T. C. (2018). Product/Service-Systems for a Circular Economy: The Route to Decoupling Economic Growth from Resource Consumption? Journal of Industrial Ecology. DOI : $10.1111 /$ jiec. 12747

Limitations. Ecological Economics 143: 37-46.

Laitala, K. and I.G. Klepp. 2015. Clothing disposal habits and consequences for life cycle assessment (LCA). Handbook of Life Cycle Assessment (LCA) of Textiles and Clothing. Elsevier Ltd.

Laurent, A., S.I. Olsen, and M.Z. Hauschild. 2012. Limitations of carbon footprint as indicator of environmental sustainability. Environmental Science and Technology 46(7): 4100-4108.

Lieder, M. and A. Rashid. 2015. Towards Circular Economy implementation: A comprehensive review in context of manufacturing industry. Journal of Cleaner Production 115: 36-51

Lindahl, M., E. Sundin, and T. Sakao. 2014. Environmental and economic benefits of Integrated Product Service Offerings quantified with real business cases. Journal of Cleaner Production 64: 288-296.

Madsen, M.B. 2015. Deleøkonomiens klimapotentiale [The climate potential of the sharing economy]. Copenhagen, Denmark: CONCITO. http://www.concito.dk/udgivelser/deleoekonomiens-klimapotentiale.

Mair, S., A. Druckman, and T. Jackson. 2014. Global inequities and emissions in Western European textiles and clothing consumption. Journal of Cleaner Production 132: 57-69.

Manzini, E. and C. Vezzoli. 2002. Product-Service Systems and Sustainability: opportunities for sustainable solutions. UNEP and Politecnito di Milano University, Milan.

McDonough, W. and M. Braungart. 2002. Cradle to Cradle: Remaking the Way We Make Things. 2nd ed. New York: North Point Press.

McDonough, W. and M. Braungart. 2013. The Upcycle: Beyond Sustainability - Designing for Abundance. New York: North Point Press.

Mont, O. 2004. Reducing life-cycle environmental impacts through systems of joint use. Greener Management International (45): 63-77.

Morelli, N. 2006. Developing new product service systems (PSS): methodologies and operational tools. Journal of Cleaner Production 14(17): 1495-1501.

Mylan, J. 2015. Understanding the diffusion of Sustainable Product-Service Systems: Insights from the sociology of consumption and practice theory. Journal of Cleaner Production 97: 13-20.

Niero, M. and M.Z. Hauschild. 2017. Closing the Loop for Packaging: Finding a Framework to Operationalize Circular Economy Strategies. Procedia CIRP 61: 685-690.

Nordic Council of Ministers. 1997. Environmental impact of consumer goods: A guideline for specific assessments. Copenhagen: TemaNord.

Oberender, C. and H. Birkhofer. 2004. The eco-value analysis - an approach to assigning environmental impacts and costs to customers’ demands. In DS 32: Proceedings of DESIGN 
Kjær, L. L., Pigosso, D. C. A., Niero, M., Bech, N. M., \& McAloone, T. C. (2018). Product/Service-Systems for a Circular Economy: The Route to Decoupling Economic Growth from Resource Consumption? Journal of Industrial Ecology. DOI : $10.1111 /$ jiec. 12747

2004, the 8th International Design Conference, ed. by Marjanovic D., 1553-1558. Dubrovnik, Croatia: Design Society.

Ongondo, F.O. and I.D. Williams. 2011. Mobile phone collection, reuse and recycling in the UK. Waste Management 31(6): 1307-1315.

Pagoropoulos, A., L.L. Kjaer, Y. Dong, M. Birkved, and T.C. Mcaloone. 2017. Economic and Environmental Impact Trade-Offs Related to In-Water Hull Cleanings of Merchant Vessels. Journal of Industrial Ecology In press.

Pauli, G.A. 2010. The Blue Economy: 10 Years, 100 Innovations, 100 Million Jobs. Paradigm Publications.

Pauw, I.C. De, E. Karana, P. Kandachar, and F. Poppelaars. 2014. Comparing Biomimicry and Cradle to Cradle with Ecodesign: A case study of student design projects. Journal of Cleaner Production 78: 174-183.

Pigosso, D.C.A. and T.C. McAloone. 2016. Maturity-based approach for the development of environmentally sustainable product/service-systems. CIRP Journal of Manufacturing Science and Technology 15: 33-41.

Pigosso, D.C.A., S.R. Souza, A.G. Filho, A.R. Ometto, and H. Rozenfeld. 2010. Is the Industrial Product-Service System really sustainable? In Proceedings of the 2nd CIRP IPS2 Conference 2010, 59-65.

Salazar, C., A. Lelah, and D. Brissaud. 2014. Eco-designing Product Service Systems by degrading functions while maintaining user satisfaction. Journal of Cleaner Production 87: 452-462.

Scheepens, A.E., J.G. Vogtländer, and J.C. Brezet. 2016. Two life cycle assessment (LCA) based methods to analyse and design complex (regional) circular economy systems. Case: Making water tourism more sustainable. Journal of Cleaner Production 114: 257-268.

Stahel, W.R. 2010. The Performance Economy. 2nd ed. London: Palgrave MacMillan.

Strothman, P. and G. Sonnemann. 2017. Circular economy, resource efficiency, life cycle innovation: same objectives, same impacts? International Journal of Life Cycle Assessment 22(8): 1327-1328.

Thomas, V.M. 2003. Demand and Dematerialization Impacts of Second-Hand Markets - Reuse or More Use? Journal of Industrial Ecology 7(2): 65-78.

Tojo, N., B. Kogg, N. Kiørboe, B. Kjær, and K. Aalto. 2012. Prevention of Textile Waste - Material flows of textiles in three Nordic countries and suggestions on policy instruments. TemaNord 2012:545. Copenhagen, Denmark.

Tukker, A. 2004. Eight types of product-service system: eight ways to sustainability? Experiences from SusProNet. Business Strategy and the Environment 13(4): 246-260. 
Kjær, L. L., Pigosso, D. C. A., Niero, M., Bech, N. M., \& McAloone, T. C. (2018). Product/Service-Systems for a Circular Economy: The Route to Decoupling Economic Growth from Resource Consumption? Journal of Industrial Ecology. DOI : $10.1111 /$ jiec. 12747

Tukker, A. 2015. Product services for a resource-efficient and circular economy - A review. Journal of Cleaner Production 97: 76-91.

Tukker, A. and U. Tischner. 2006a. Product-services as a research field: past, present and future. Reflections from a decade of research. Journal of Cleaner Production 14(17): 1552-1556.

Tukker, A. and U. Tischner. 2006b. New Business for Old Europe: product-service development, competitiveness and sustainability. Ed. by Arnold Tukker and Ursula Tischner. Sheffield, South Yorkshire, England: Greenleaf Publishing.

UNEP. 2011. Decoupling Natural Resource Use and Environmental Impacts from Economic Growth. A Report of the Working Group on Decoupling to the International Resource Panel.

VIGGA. 2016. The VIGGA product-service-system. www.vigga.us/in-english/. Accessed May 29, 2017.

Vivanco, D.F. and E. Van Der Voet. 2014. The rebound effect through industrial ecology's eyes : a review of LCA-based studies. International Journal of Life Cycle Assessment 19(12): 19331947.

Washa. 2016. Rent vaske- og rensetøj leveret lige til døren [washed and dry-cleaned clothes delivered to the door]. https://washa.dk/. Accessed May 29, 2017.

Weidema, B.P., T. Ekvall, and R. Heijungs. 2009. Guidelines for application of deepened and broadened LCA. Deliverable D18 of Work Package 5 of the CALCAS Project. http://www.calcasproject.net.

WRAP. 2010. Environmental life cycle assessment (LCA) study of replacement and refurbishment options for domestic washing machines.

Zink, T. and R. Geyer. 2017. Circular Economy Rebound. Journal of Industrial Ecology 21(3): 93602.

\section{<heading level $1>$ About the authors}

Louise Laumann Kjær is a PhD researcher within the Section of Engineering Design and Product Development at the Department of Mechanical Engineering, Technical University of Denmark, Denmark. Daniela C. A. Pigosso is a Senior Researcher at Section of Engineering Design and Product Development, Department of Mechanical Engineering, Technical University of Denmark, Denmark. Monia Niero is a researcher at the Division for Quantitative Sustainability Assessment, Department of Management Engineering, Technical University of Denmark, Denmark. Nynne Marie Bech holds a master of Geography and Geoinformatics from Department of Geosciences and Natural Resource Management, University of Copenhagen, Denmark. She works as a consultant within environmental footprinting at NIRAS, Allerød, Denmark. Tim C. McAloone is Professor of 
Kjær, L. L., Pigosso, D. C. A., Niero, M., Bech, N. M., \& McAloone, T. C. (2018). Product/Service-Systems for a Circular Economy: The Route to Decoupling Economic Growth from Resource Consumption? Journal of Industrial Ecology. DOI : $10.1111 /$ jiec. 12747

Sustainable Product/Service-Systems at the Section of Engineering Design and Product

Development, Department of Mechanical Engineering, Technical University of Denmark, Denmark. 